\title{
RUMUŃSKA TERMINOLOGIA RELIGIJNA A PODZIAŁY WYZNANIOWE
}

\author{
TOMASZ KLIMKOWSKI
}

\begin{abstract}
Religious terminology in Romanian and confessional divisions.
The article presents some terminological differences between various Christian denominations existing on Romanian territory, mainly between the Romanian Orthodox Church, prevalent in Romania, on the one hand and the Greek Catholic Church (the Uniats) and the Roman Catholic Church on the other. These differences are usually a result of a conscious linguistic policy of both Catholic rites and various Protestant and Neo-Protestant denominations. They are also reflected in the use of different forms of the name Jesus Christ, which exists in at least three versions. Even in the case of the same, common notions, the new denominations often introduce different terms, mainly Latin and Romance neologisms, in order to mark an external and formal difference from the Orthodox Church, whose terminology is of mostly Greek and Slavonic origin.
\end{abstract}

STRESZCZENIE. Artykuł przedstawia wybrane różnice terminologiczne między różnymi odłamami chrześcijaństwa występującymi na terenie Rumunii, głównie między większościowym w Rumunii prawosławiem a katolicyzmem obrządku greckiego (unici) i łacińskiego (rzymscy katolicy). Różnice te są najczęściej wynikiem świadomej polityki językowej obu odmian katolicyzmu oraz różnych denominacji protestanckich i neoprotestanckich. Przejawiają się one również w użyciu różnych form imienia 'Jezus Chrystus', funkcjonującego w trzech przynajmniej wersjach. Nawet w przypadku tych samych, wspólnych pojęć nowsze wyznania wprowadzają często odmienne terminy, na ogół neologizmy łacińsko-romańskie, aby w ten sposób odróżnić się również zewnętrznie i formalnie od prawosławia, stosującego terminologię głównie grecko-słowiańskiego pochodzenia.

Autor: Tomasz Klimkowski, Uniwersytet im. Adama Mickiewicza, Wydział Neofilologii, Al. Niepodległości 4, 61-874 Poznań, Polska, tomasz.klimkowski@amu.edu.pl, ORCID ID: https://orcid.org/0000-0003-0376-3110

Słowa kluczowe: język rumuński, terminologia religijna, Rumuński Kościół Prawosławny, Kościół greckokatolicki, Kościół rzymskokatolicki, Jezus Chrystus

Keywords: Romanian, religious terminology, Romanian Orthodox Church, Greek Catholic Church, Roman Catholic Church, Jesus Christ

Balcanica Posnaniensia. Acta et studia, XXVII, Poznań 2020, Wydawnictwo Wydziału Historii UAM, pp. 181194, ISBN 978-83-66355-54-5, ISSN 0239-4278. Polish text with summaries in English and Polish.

doi.org/10.14746/bp.2020.27.12 
Zgodnie z Ustawa nr 489/2006 o wolności religijnej (Legea nr. 489/2006 privind libertatea religioasă), zwaną Prawem o wyznaniach religijnych (Legea cultelor) ${ }^{1}$, państwo rumuńskie uznaje oficjalnie 18 wyznań:

1. Rumuński Kościół Prawosławny (Biserica Ortodoxă Română)

2. Serbskie Biskupstwo Prawosławne Timișoary (Episcopia Ortodoxă Sârbă de Timişoara)

3. Kościół Rzymskokatolicki (Biserica Romano-Catolică)

4. Kościół Rumuński Zjednoczony z Rzymem, Greckokatolicki (Biserica Română Unită cu Roma, Greco-Catolică)

5. Arcybiskupstwo Kościoła Ormiańskiego (Arhiepiscopia Bisericii Armene)

6. Rosyjski Staroobrzędowy Kościół Prawosławny w Rumunii (Biserica Ortodoxă Rusă de Rit Vechi din România)

7. Kościół Reformowany w Rumuniii (Biserica Reformată din România)

8. Kościół Ewangelicki C.A. w Rumunii (Biserica Evanghelică C.A. din România)

9. Kościół Ewangelicko-Luterański w Rumunii (Biserica Evanghelică Lutherană din România)

10. Kościół Unitariański w Siedmiogrodzie (Biserica Unitariană din Transilvania)

11. Chrześcijańskie Wyznanie Baptystyczne - Związek Chrześcijańskich Kościołów Baptystycznych w Rumunii (Cultul Creștin Baptist - Uniunea Bisericilor Creștine Baptiste din România)

12. Chrześcijański Kościół Ewangeliczny w Rumunii-Związek Chrześcijańskich Kościołów Ewangelicznych w Rumunii (Biserica Creștină După Evanghelie din România - Uniunea Bisericilor Creștine după Evanghelie din România)

13. Rumuński Kościół Ewangelicki (Biserica Evanghelică Română)

14. Chrześcijańskie Wyznanie Zielonoświątkowe - Apostolski Kościół Boży w Rumunii (Cultul Creștin Penticostal - Biserica lui Dumnezeu Apostolică din România)

15. Kościół Adwentystyczny Dnia Siódmego w Rumunii (Biserica Adventistă de Ziua a Șaptea din România)

16. Związek Gmin Żydowskich w Rumunii - Wyznanie Mojżeszowe (Federația Comunităților Evreiești din România - Cultul Mozaic)

17. Wyznanie Muzułmańskie (Cultul Musulman)

18. Związek Religijny Świadków Jehowy (Organizația Religioasă „Martorii lui Iehova").

1 Legea $n r$. 489/2006 privind libertatea religioasă, http://www.arhiva.culte.gov.ro/_site/culte/deta liu-legislatie/vrs/IDleg/18.html [dostęp: 15.06.2020]. 
Spośród osiemnastu oficjalnie uznawanych wyznań religijnych szesnaście to różne odłamy chrześcijaństwa². Różnice między nimi mają najczęściej charakter merytoryczny, tzn. dotyczą doktryny, rytuału, etyki, organizacji czy architektury kościelnej. Czasami mają one jednak charakter czysto formalny, terminologiczny - te same pojęcia mogą być wyrażane za pomocą różnych terminów, często w celu sztucznego odróżnienia się od innego wyznania, jeśli różnice natury merytorycznej nie są zbyt duże.

Celem niniejszego artykułu jest zasygnalizowanie różnic terminologicznych między różnymi odłamami chrześcijaństwa występującymi na terenie Rumunii, głównie między prawosławiem a katolicyzmem obrządku greckiego (unici) i łacińskiego (rzymscy katolicy). Siłą rzeczy, najbardziej konserwatywny charakter ma terminologia prawosławia, jako wyznania nie tylko większościowego, ale również tradycyjnego, podczas gdy terminologia używana przez grecki i rzymski katolicyzm, bazując ciągle na prawosławnej, przejawia już szereg innowacji. Ma to oczywiście uzasadnienie historyczne: są to - w rumuńskich realiach - wyznania nowsze, późniejsze od prawosławia (czy to w ogóle, jak wyznanie unickie, powstałe w Siedmiogrodzie ok. 1700 r., czy też pod względem językowym, gdyż o rumuńskojęzycznych wspólnotach rzymskokatolickich na ziemiach rumuńskich można mówić dopiero w XIX w. ${ }^{3}$ ). Podobną, innowacyjną politykę językową prowadzą także różne wyznania protestanckie, $w$ tym denominacje o charakterze neoprotestanckim i postprotestanckim (Świadkowie Jehowy).

Leksyka rumuńska w ogóle stanowi amalgamat elementów różnego pochodzenia. Można je podzielić na dwie zasadnicze warstwy: starorumuńską - wyrazy „rodzime”, „,autochtonizmy” (rum. neaoșisme) - i noworumuńską - „neologizmy”, wyrazy zapożyczone w okresie relatynizacji, tj. w XVIII-XX w. (rum. neologisme) ${ }^{4}$. Do pierwszej warstwy należą zarówno latynizmy odziedziczone (zasadniczy trzon leksyki rumuńskiej), jak i dawne zapożyczenia: paleobałkanizmy, paleogrecyzmy, paleoslawizmy;

2 Na powyższej liście nie figuruje Kościół Staroprawosławny (Biserica Ortodoxă de Stil Vechi), powstały w latach 20. ubiegłego wieku w wyniku odmowy przyjęcia przez część hierarchów kalendarza gregoriańskiego, postrzeganego jako przejaw „papizmu”, ponieważ do tej pory nie ma on statusu Kościoła uznanego przez państwo i funkcjonuje jedynie jako stowarzyszenie religijne.

3 Pierwotne chrześcijaństwo bałkanoromańskie miało charakter rzymski, na co wskazuje łacińskie pochodzenie najważniejszych terminów religijnych używanych w rumuńskim i w innych językach bałkanoromańskich; łacina była też zapewne językiem używanym w liturgii w zromanizowanych prowincjach Imperium Rzymskiego. Z drugiej jednak strony prowincje te, po podziale państwa, znalazły się w granicach Cesarstwa Wschodniorzymskiego i już wtedy musiały znaleźć się pod silnym wpływem tradycji wschodniej, bizantyńskiej, która ostatecznie - po chrystianizacji Słowian południowo-wschodnich zdominowała Bałkany, w tym kształtujący się wówczas etnos wołoski. Oczywiście w odniesieniu do pierwszego tysiąclecia naszej ery można mówić jedynie o osobnych tradycjach kulturowych i językowych w łonie chrześcijaństwa, a późniejsze podziały religijne (prawosławie i katolicyzm) mają zastosowanie dopiero od czasów pełnego i późnego średniowiecza.

4 Podział za: T. Klimkowski, Autochtonizmy i neologizmy w rumuńskiej terminologii prawniczej w kontekśsie przektadu polsko-rumuńskiego, w: B. Walkiewicz, K. Kęsicka (red.), Norma a uzus II. Przekład specjalistyczny w perspektywie globalizacji, Poznań 2017, s. 79-80. 
slawizmy (wraz z cerkiewizmami), bizantynizmy, turkizmy, hungaryzmy; neogrecyzmy, osmanizmy oraz formacje rodzime. Drugą warstwę tworzą późniejsze zapożyczenia: latynizmy, galicyzmy, italianizmy oraz anglicyzmy, a także nowsze formacje rodzime (często kalki z języków zachodnich).

W rezultacie leksyka współczesnego języka rumuńskiego i używana w nim terminologia religijna zawierają szereg dubletów, a nawet całych serii synonimicznych. Jako że synonimia absolutna, jeśli dochodzi do niej na skutek uwarunkowań historycznych (jak w rumuńskim), jest nieekonomiczna, nienaturalna i niewygodna, język usuwa ją na różne sposoby. Następuje to poprzez eliminację jednego z terminów bądź specjalizację stylistyczną, kolokacyjno-frazeologiczną czy nawet semantyczną synonimów tworzących dany dublet lub serięe .

I tak, w przypadku słownictwa o charakterze religijnym, eliminację jednego z elementów ilustruje seria następujących synonimów (podanych zgodnie z chronologią ich pojawienia się w języku): cazanie (< słow. казанїє) - didahie $\left(<\right.$ gr. $\left.\delta i \delta \alpha \chi \eta^{\prime}\right)-$ omilie (< gr. ó $\mu \imath \lambda i \alpha)$ - predică (< w1. predica) 'kazanie'6. O ile cazanie, omilie i predică rejestrowane są przez współczesne słowniki bez żadnych kwalifikatorów, to didahie opatrywane jest w nich adnotacją ,przestarzałe"7. Nie jest ono również zaświadczone w korpusie współczesnego języka rumuńskiego, w którym zresztą rzadki jest także termin cazanie, co pokazuje, że ze wszystkich czterech synonimów używane są współcześnie głównie predică i omilie ${ }^{8}$.

Przykładem specjalizacji stylistycznej synonimów jest dublet: preot $(<$ łac. presbyter, latynizm odziedziczony) - popă (< słow. попъ < gr. $\pi \dot{\alpha} \pi \alpha \varsigma)$ 'ksiądz'. Podczas gdy preot ma charakter neutralny, określenie popă jest już wyraźnie potoczne i ludowe, a często również pejoratywne, co potwierdzają źródła leksykograficzne? 9

Specjalizację kolokacyjno-frazeologiczną synonimów pokazuje użycie pary wyrazowej păcat (< łac. peccatum, latynizm odziedziczony) i greșeală $(<$ a greși 'grzeszyć' < słow. грłшити) 'grzech': jako odpowiednik polskiego wyrażenia 'odpuszczać grzechy’ funkcjonuje zarówno a ierta păcatele, jak i a ierta greșelile, jednak w syntagmie 'grzech pierworodny' używa się jedynie leksemu păcat, por. păcatul

5 Klasyfikacja i charakterystyka mechanizmów usuwania lub niuansowania synonimii: ibidem, s. $80-81$.

$6 \mathrm{Tu}$ i poniżej etymologia podawana jest za: DER $=$ A. Ciorănescu, Dicționarul etimologic al limbii române, thum. T. Șandru Mehedinți, M. Popescu Marin, București 2002; DEX = I. Coteanu, L. Mareș (red.), Dicționarul explicativ al limbii române, București 1998, https://dexonline.ro/ [dostęp: 12.07.2020]; MDA = M. Sala, I. Dănăilă (red.), Micul dicționar academic, București 2010, https://dexonline.ro/ [dostęp: 12.07 .2020$]$.

7 Współczesne słowniki, tj. z lat 1955-2010: DLRLC = A. Rosetti (red.), Dicționarul limbii romîne literare contemporane, București 1955-1957; DEX, op. cit.; MDA, op. cit.; wszystkie słowniki z poziomu strony: https://dexonline.ro/ [dostęp: 12.07.2020].

8 CoRoLa. Corpus computațional de referință pentru limba română contemporană, http://corola.ra cai.ro/ [dostęp: 10.08.2020].

9 Ludowe lub potoczne, czasami w znaczeniu pejoratywnym (DLRLC, op. cit.); ludowe (DEX, op. cit.); ludowe i potoczne (MDA, op. cit.). 
strămoșesc/originar, przy czym - jak widać - wymienna jest przydawka przymiotnikowa o znaczeniu 'pierworodny', nienależąca w zasadzie do terminologii religijnej: strămoșesc (autochtonizm) vs originar (neologizm).

Najbardziej zaawansowaną ewolucję przedstawiają przypadki specjalizacji semantycznej różnych synonimów, mimo że niekiedy może być ona dość subtelna. Na przykład różnica między wspomnianymi wyżej synonimicznymi terminami: preot (łac.) i popă (gr.-słow.) 'ksiądz', mająca charakter przede wszystkim stylistyczny (rejestr neutralny vs niski), opisywana jest również w kategoriach semantycznych: preot miałby być absolwentem wyższego, a popă - niższego seminarium duchownego (przynajmniej w realiach XIX-wiecznej Rumunii). Najbardziej wymownym ze wszystkich przykładem jest zaś ewolucja semantyczna terminu troiță (< słow. тронца), niegdyś synonimu do Treime (< trei 'trzy') 'Trójca (Święta)', a obecnie rzeczownika konkretnego o znaczeniu 'krzyż przydrożny' lub 'trzyczęściowa ikona' ${ }^{10}$.

Zjawiskiem, na które chcemy jednak zwrócić szczególną uwagę, jest specjalizacja konfesjonalna różnych synonimów, czyli wykorzystanie synonimii terminologicznej do oddania różnic wyznaniowych. Warto nadmienić, że najważniejsze prace leksykograficzne nie sygnalizują tego rodzaju rozróżnień; pewne spostrzeżenia pod tym względem pozwala uczynić dopiero analiza uzusu językowego poszczególnych Kościołów. Na ogół jest to rozróżnienie czysto formalne i nie odzwierciedla różnic teologicznych, jednak może być ono dość konsekwentne i rygorystyczne.

Różnice między poszczególnymi synonimami są niekiedy minimalne - wyłącznie słowotwórcze. Przykładem zastąpienia starszego derywatu nowszym, polegającego jedynie na wymianie sufiksu, jest apostolesc (utworzone od apostol 'apostoł' na wzór cerkiewnosłowiańskiego апостомьскїй), występujące w wyznaniu wiary (apostolească Biserică 'apostolski Kościół’), zamienione w wersji grecko- i rzymskokatolickiej na apostolic:

\footnotetext{
rum. prawosł. [Cred] Întru una, sfântă, sobornicească şi apostolească Biserică.

rum. gr.-kat. [Cred] Întru Una, Sfântă, Catolică și Apostolică Biserică.

rum. rzym.-kat. Cred într-una, sfântă, catolică şi apostolică Biserică.

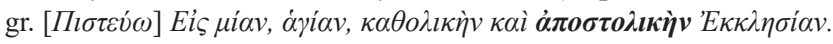

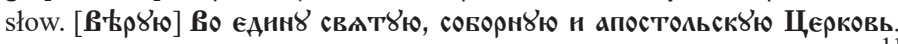

łac. [Credo] Et [in] unam, sanctam, catholicam et apostolicam Ecclesiam. ${ }^{11}$

'Wierzę w jeden, święty, powszechny i apostolski Kościół'.
}

Mimo że rumuński sufiks przymiotnikowy -esc odziedziczony jest z łaciny $(<$ łac. -iscus), a wpływ słowiański w tym przypadku polegał jedynie na znacznym rozsze-

10 DLRLC, op. cit.; DEX, op. cit.; MDA, op. cit.

11 Fragmenty wyznania wiary w językach: rumuńskim, greckim i łacińskim pochodzą z: CrezulTatăl nostru în unsprezece limbi, București 2015, s. 14, 17, 21, 26, 32. Fragment w języku cerkiewnosłowiańskim zaczerpnięto z publikacji: G. Podlaski (red.), Молитвословъ. Моdlitewnik prawosławny, Białystok 2002, s. 16. 
rzeniu jego użycia, na wzór analogicznych derywatów słowiańskich ${ }^{12}$, derywaty, w których sufiks ten występował, straciły z czasem na znaczeniu na rzecz neologizmów, najczęściej z sufiksami -ic, -il, -in, (niejednokrotnie opartych na innych rdzeniach niż dany autochtonizm lub w ogóle nieanalizowalnych na gruncie rumuńskim). Wymieniając tylko leksemy o charakterze religijnym, byłyby to następujące synonimiczne pary przymiotników:

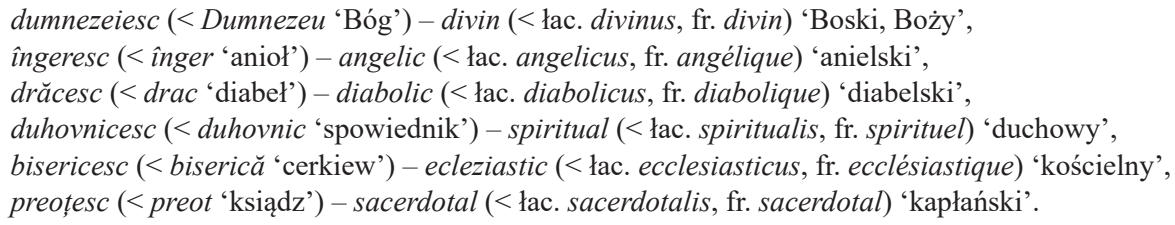

Neologizmy zachowują ciągle bardziej techniczny wydźwięk (wytwarzając czasami dodatkowe niuanse znaczeniowe o niekoniecznie religijnym charakterze), jednak przenikają również do terminologii ściśle religijnej (głównie katolickiej), często $\mathrm{w}$ połączeniu $\mathrm{z}$ innymi neologizmami, przeciwstawiając się wówczas starszym, „autochtonicznym” syntagmom, por. dumnezeiască liturghie, slujbă dumnezeiască (w prawosławiu) - serviciu divin 'nabożeństwo' (również w prawosławiu, ale częściej w greckim i rzymskim katolicyzmie).

Inne różnice między wyznaniami chrześcijańskimi dotyczą pojęć: 'Duch Święty', 'grzech', 'zmiłować się':

rum. prawosł. Și întru Duhul Sfânt, Domnul de viață Făcătorul, Carele de la Tatăl purcede rum. gr.-kat. Și întru Spiritul Sfânt, Domnul de viață Făcătorul, care de la Tatăl purcede rum. rzym.-kat. Cred în Duhul Sfânt, Domnul și de viață dătătorul, care de la Tatăl și de la Fiul purcede ${ }^{13}$

'I w Ducha Świętego, Pana [i] Ożywiciela, który od Ojca [i Syna] pochodzi'

rum. prawosł. și ne iartă nouă greșalele noastre, precum și noi iertăm greșiților noștri rum. gr.-kat. și ne iartă nouă păcatele noastre, precum și noi iertăm greșiților noștri rum. rzym.-kat. și ne iartă nouă greșelile noastre, precum și noi iertăm greșiților noștri ${ }^{14}$ 'i odpuść nam nasze winy, jako i my odpuszczamy naszym winowajcom'

rum. prawosł. Doamne miluiește

rum. gr.-kat. Doamne, îndură-Te spre noi

rum. rzym.-kat. Doamne, miluiește-ne $\boldsymbol{e}^{15}$

'Panie, zmiluj się'

12 Zob. T. Klimkowski, Influențe slave vechi asupra morfologiei și sintaxei limbii române, Alba Iulia 2011, s. 168-170.

13 Crezul - Tatăl nostru în unsprezece limbi, op. cit., s. 14, 17, 21.

14 Ibidem, s. 15, 18, 22.

15 prawosł.: Sfânta și Dumnezeiasca Liturghie a Sfântului Ioan Gură de Aur, w: Carte de rugăciuni, Alba Iulia 2003, s. 194-250; gr.-kat.: Liturghia Sfântului Ioan Gură-de-Aur, w: Carte de rugăciuni, http:// www.greco-catolic.ro/rugaciuni.asp?autor=gotia\&id=10 [dostęp 10.07.2020]; rzym.-kat.: Rânduiala 
Jak widać, grekokatolicy są terminologicznie nierzadko bardziej łacińscy niż rzymscy katolicy, por. Spirit 'Duch' ( $<$ łac. Spiritus), a se îndura 'zmiłować się' ( $<$ łac. indurare), păcat 'grzech' $\left(<\right.$ łac. peccatum ${ }^{16}$. Ci ostatni - paradoksalnie - używają często tradycyjnej, prawosławnej terminologii, głównie słowiańskiego pochodzenia, np. Duh 'Duch' (< słow. А૪Х'ъ), a milui 'zmiłować się' (< słow. мнмоватн), greșeală 'grzech' (< a greși 'grzeszyć' < słow. грłшитн). Mimo wcześniejszych prób w tym kierunku Kościół unicki zrezygnował jednak z wprowadzenia zamiast sfânt 'święty' (< słow. свАттъ) neologicznego terminu sânt (< łac. sanctus) ${ }^{17}$ (czyli właściwie z latynizacji formy sfânt do sânt), a zatem drugi człon syntagmy 'Duch Święty' pozostaje wspólny dla wszystkich tych wyznań.

Czasami chęć odróżnienia się od innego wyznania ma jednak uzasadnienie merytoryczne, np. w przypadku odmiennego rozumienia danego pojęcia - w takiej sytuacja zachodzi potrzeba użycia konkretnego terminu w celu lepszego wyrażenia tego pojęcia lub uniknięcia nieporozumień. I tak, wracając do serii „autochtonicznych” i „,neologicznych” przymiotników oraz tekstu wyznania wiary (zob. wyżej), dawniejsze sobornicesc 'soborowy, synodalny' (pochodzące od cerkiewnosłowiańskiego coворный) w połączeniu z rzeczownikiem Biserică 'Kościół, Cerkiew' (syntagma sobornicească Biserică użyta w wyznaniu wiary w znaczeniu 'powszechny Kościół' ${ }^{18}$ ) nie wymienia się w wersji grecko- i rzymskokatolickiej na któryś ze swoich neologicznych synonimów: sinodal, sinodic, ecumenic, lecz podlega reinterpretacji w kontekście wyznania wiary i zastąpione zostaje neologizmem catolic $(<$ łac. catholicus, fr. catholique) (= catolică Biserică), rozumianym jako 'powszechny, uniwersalny, ogólnoświatowy', ale również jako 'katolicki', czyli tożsamy z konkretnym odłamem chrześcijaństwa. Ten nowy wariant znacznie już oddala się od swego słowiańskiego odpowiednika i pierwowzoru dla wersji prawosławnej (соворный), stanowiąc powrót

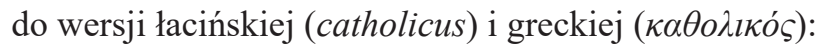

rum. prawosł. [Cred] Întru una, sfântă, sobornicească şi apostolească Biserică.

rum. gr.-kat. [Cred] Întru Una, Sfântă, Catolică şi Apostolică Biserică.

rum. rzym.-kat. Cred într-una, sfântă, catolică și apostolică Biserică.

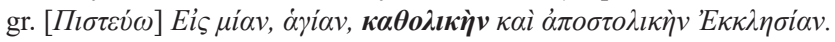

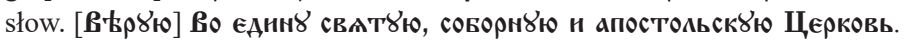

Sfintei Liturghii, w: Preces. Carte de rugăciuni, Iași 1996, http://www.ercis.ro/liturgie/preces.asp?id=14 [dostęp: 10.07.2020].

16 Są to zarówno łacińskie neologizmy (Spirit), jak i latynizmy odziedziczone (a se indura, păcat).

17 Wariant ten miał oparcie w ludowej formie sân(t), sântă, występującej głównie - lub jedynie w złożeniach z imionami świętych oznaczających święta i nazwy miejscowe, jak np. Sânpetru 'Święty Piotr'.

18 Tak w jednej z polskich wersji prawosławnego wyznania wiary, na wzór tradycyjnej wersji katolickiej (Boska Liturgia świętego ojca naszego Jana Chryzostoma, thum. H. Paprocki, s. 15, http://www.litur gia.cerkiew.pl/pages/File/docs/urgia_jana_chryzostoma.pdf [dostęp: 15.05.2020]). W innym przekładzie prawosławnym (tego samego tłumacza) - katolicki (sic!) Kościót (Boska Liturgia świętego ojca naszego Jana Chryzostoma, w: Liturgie Kościoła prawosławnego, tłum. H. Paprocki, Kraków 2003, s. 90). W prawosławnej wersji rumuńskiej Kościół jest sobornicesc, czyli dosłownie ‘soborowy, synodalny'. 
łac. [Credo] Et [in] unam, sanctam, catholicam et apostolicam Ecclesiam. ${ }^{19}$

'Wierzę w jeden, święty, powszechny i apostolski Kościół.'

Regularne różnice między wyznaniami dotyczą adaptacji nazw własnych, jednak szczególne emocje wzbudza - co zresztą zrozumiałe - wymowa i pisownia imienia Jezus Chrystus ${ }^{20}$. Tradycyjny zapis, Iisus Hristos, pochodzi od greckiego 'I $\eta \sigma \tilde{v} \varsigma$

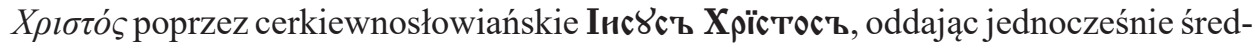
nio- i nowogrecką oraz cerkiewnosłowiańską realizację fonetyczną /ii' sus xri' stos/.

Nagłosowa sekwencja /ii/ w greckiej formie imienia 'Jezus' stanowi oczywiście normalny rozwój fonetyczny dawniejszego /iع:/ (stąd łacińska wersja Iēsūs, Jēsūs

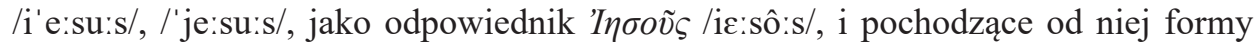
w językach zachodnioeuropejskich, zawierające różne refleksy samogłoski /e:/). We współczesnym języku rumuńskim pierwotne /ii/ (hiatus) lub /ji/ (dyftong) w imieniu Jezus jest już jednak realizowane jako pojedyncza samogłoska /i/21, stąd coraz częstszy zapis Isus zamiast tradycyjnego Iisus. Z językoznawczego punktu bardziej uzasadniona jest druga pisownia, ponieważ współczesna ortografia rumuńska opiera się na zasadzie fonetycznej; pierwsza -wcześniejsza i tradycyjna - ma w realiach współczesnej rumuńszczyzny charakter etymologizujący. Należy dodać, że - poza izolowanymi przypadkami ${ }^{22}$ - nie podejmowano prób odtworzenia w rumuńskim pierwotnej (tzn. starogreckiej i łacińskiej) wymowy tej formy z /e/ zamiast /i/.

Co się zaś tyczy tytułu 'Chrystus', to w okresie relatynizacji, pod wpływem łacińskiej formy Christus, wymawianej w Rumunii /'kristus/, pojawiła się w rumuńskim alternatywna do Hristos /xri'stos/ forma Cristos/kri'stos/. Jeśli cho-

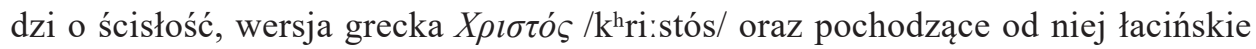
Chrīstus /'k $\mathrm{k}^{\mathrm{h}}$ i.stus/ miały pierwotnie w nagłosie aspirowane $/ \mathrm{k}^{\mathrm{h}}$, które w grece przeszło później $\mathrm{w} / \mathrm{x} /$, stąd /xris'tos/, a w łacinie - w/k/, dając formę /'kristus/. Uzasadnione są zatem oba fonetyzmy (/x/ ma oparcie $\mathrm{w}$ grece, a $/ \mathrm{k} / \mathrm{w}$ łacinie), jednak zakończenie -os na tyle silnie wskazuje na greckie pochodzenie, że częściowo tylko zlatynizowane Cristos stanowi zwykłą hybrydę. Poprawnie zaadaptowane powinno mieć postać Crist ${ }^{23}$, która to forma faktycznie istnieje, lecz ma

19 Źródło cytatów: zob. przyp. 11.

20 Najpełniejszą analizę tego przypadku stanowi studium E. Munteanu, Un caz de inconsecvență ortografică cu motivație confesională: I(i)sus H(ch)ristos, „Anuar de Lingvistică și Istorie Literară”, 20042006 , t. 44-46, s. 31-43.

21 C. Ghioancă, Isus sau Iisus? Care este varianta corectă?, http://bisericaadonai.ro/isus-sau-iisus/ [dostęp: 14.08.2020].

22 Jest to przede wszystkim Fragment Todorescu (Fragmentul Todorescu), inaczej Śpiewnik (Cartea de cântece), wydany łacinką, w ortografii węgierskiej, w siedmiogrodzkim Klużu między 1571 a 1575 r., gdzie pojawia się zapis Iesus, co należy interpretować jako Iesus /jesus/ lub Iezuș /jezuf/ (I. Gheție, Fragmentul Todorescu. Text stabilit, studiu filologic, studiu lingvistic şi indice de I. Gheție, w: Texte româneşti din secolul al XVI-lea, red. I. Gheție, București 1982, s. 336-343).

23 We wspomnianym wyżej Fragmencie Todorescu, w połączeniu z Iesus używa się form Christus i Cristus, interpretowanych jako Cristus /'kristus/ lub Cristuș /'kristuf/. Syntagma Iesus Cristus stanowi 
charakter marginalny i raczej nie występuje w języku religijnym ${ }^{24}$; co ciekawe, w słowniku pojęć religijnych Stoiana zaświadczony jest też wariant Hrist(os) (czyli pośrednio Hrist) z odsyłaczem do Iisus Hristos $^{25}$. Tradycje pierwszej oficjalnej ortografii rumuńskiej w alfabecie łacińskim (ortografia etymologizująca z II poł. XIX w.) kontynuuje trzeci sposób zapisu, Christos, popularny obecnie wśród intelektualistów o formacji klasyczno-humanistycznej ${ }^{26}$, ponieważ wpisuje się konsekwentnie w praktykę transkrybowania litery $\langle\chi\rangle$ w słowach starogreckich jako $<\mathrm{ch}>$ (jak w łacinie i innych językach europejskich). Zwolennicy tego ostatniego zapisu często widzą w nim swoisty kompromis: jako że jest niejako sumą obu alternatywnych wersji, Cristos i Hristos, może być odczytywany zarówno jako /xri'stos/, jak i /kri'stos/, w zależności od preferencji.

Najważniejszy słownik normatywny ostatnich lat (DOOM) nie przynosi zdecydowanego rozstrzygnięcia ani w kwestii imienia 'Jezus', ani w sprawie tytułu 'Chrystus'. Pod hasłem Iisus znajduje się odsyłacz do Isus, lecz pod hasłem Isus podano również formę Iisus jako oboczną (Isus/Iisus). Hasło Cristos z kolei zawiera odsyłacz do Hristos, gdzie Cristos pojawia się jednak jako alternatywna forma (Hristos/Cristos $)^{27}$. Innymi słowy, aktualna norma językowa dopuszcza w każdym przypadku po dwie formy, zalecając - jak się zdaje - połączenie Isus Hristos, skoro na pierwszym miejscu w poszczególnych hasłach podaje te właśnie warianty. Wariant Christos w ogóle nie figuruje w słowniku. Podsumowując naszą analizę, wypada stwierdzić, że wątpliwości nie budzi jedynie akcentuacja wszystkich tych form, zgodna zasadniczo z greckim (i cerkiewnosłowiańskim) pierwowzorem (tak uzus, jak i norma zawarta w DOOM mają akcent oksytoniczny w obu członach syntagmy, bez względu na wariant fonetyczny).

Przywołany wyżej słownik nie podaje żadnych informacji na temat ewentualnych preferencji wyznawców różnych odłamów chrześcijaństwa odnośnie do użycia poszczególnych wariantów (co zrozumiałe, ze względu na czysto językoznawczy charakter tej publikacji). Nie ulega jednak wątpliwości, że różne sposoby zapisu imienia Jezusa Chrystusa mogą być warunkowane różnicami wyznaniowymi, mając na celu (auto)identyfikację konkretnego odłamu chrześcijaństwa w opozycji do innych.

\footnotetext{
wczesną próbę relatynizacji imienia 'Jezus Chrystus' w oparciu o model węgierski.

24 Crist oznacza przede wszystkim 'wyobrażenie ukrzyżowanego Chrystusa' (F. Marcu, Marele dicționar de neologisme, București 2000, https://dexonline.ro/definitie/CR\%C3\%8DST [dostęp: 10.09. 2020]; poza tym możliwe, że jest to zapożyczenie z francuskiego (por. fr. Christ), a nie adaptacja formy łacińskiej.

25 I.M. Stoian, Dicționar religios, București 1994, https://dexonline.ro/definitie/Hrist [dostęp: 15.07.2020].

26 E. Munteanu, op. cit., s. 34.

27 I. Vintilă-Rădulescu (red.), Dicționarul morfologic, ortografic, ortoepic şi morfologic al limbii române (DOOM), București 2005, s. 373, 400, 195, 367.
} 
Rumuński Kościół Prawosławny używa formy Iisus Hristos jako tradycyjnej28

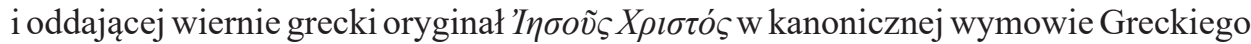
Kościoła Prawosławnego /ii 'sus xri'stos/ ${ }^{29}$. Pisownia Iisus ma jednak sztuczny charakter i podtrzymywana jest głównie siłą tradycji, gdyż we współczesnym rumuńskim - jak zauważono wyżej - upowszechniła się już wymowa /i'sus/. Służy ona również odróżnieniu Jezusa Chrystusa od innych biblijnych postaci noszących imię Jezus, np. Jezusa, syna Nuna (Jozuego), czy Jezusa, syna Syracha, których imiona zapisywane są Isus, czyli przez jedno $<\mathrm{i}>30$. Podtrzymywaniu przez prawosławnych tradycyjnej pisowni z podwójnym $<\mathrm{i}>$ ma podobno sprzyjać przekonanie, że wyraz ten zapisany przez pojedyncze $<i>$ miałby znaczyć 'osioł' ${ }^{31}$.

Zapis Isus Cristos preferowany jest z kolei przez katolików i neoprotestantów ${ }^{32}$. Predylekcję katolicyzmu obu obrządków (greckiego i łacińskiego) do formy Cristos tłumaczy się nie tylko jej latynizującym charakterem, ale również tym, że ta sama litera i głoska występują na początku wyrazów catolic 'katolik, katolicki' i cruce 'krzyż'33. Jeśli jako argument za pisownią <c> i wymową / $/$ traktować analogię do innych form, należałoby się odwołać raczej do takich wyrazów jak creștin 'chrześcijanin', creștinism 'chrześcijaństwo' czy imion typu Cristian.

Przyglądając się szczegółowej repartycji odnośnych form (lub ich kombinacji) pomiędzy poszczególne wyznania, trudno oprzeć się wrażeniu, że jest ona dość chaotyczna i przypadkowa ${ }^{34}$ :

28 E. Munteanu, op. cit., s. 33.

29 Należy zauważyć, że o istnieniu jakiejś „tradycji” można mówić jedynie w odniesieniu do tytułu 'Chrystus', gdyż teksty religijne powstałe w okresie starorumuńskim (XVI-XVIII w.) posługują się najczęściej skrótem Is. Hs., który - o ile poświadcza jednoznacznie użycie formy Hristos - może przedstawiać zarówno formę Iisus, jak i Isus. „Tradycyjną” formę Iisus można datować dopiero na I poł. XIX w. (E. Munteanu, op. cit., s. 38-40).

30 Np. już w Biblii Karola I Jozue i Jezus, syn Syracha, nazywani są Isus, a Jezus Chrystus - Iisus (Biblia adică Dumnezeiasca Scriptură a Legii Vechi şi a Celei Nouă, București 1914, s. 275, 1197, 1343 i nast.); w Biblii patriarchy Teoktysta oraz w Biblii Valeriu Anania Jozue to wprawdzie Iosua, ale już Jezus, syn Syracha, to Isus, a Jezus Chrystus - Iisus (Biblia sau Sfânta Scriptură, București 1997, s. 235, 985, 1097 i nast.; Biblia sau Sfânta Scriptură, tłum. B.V. Anania, 2012, s. 351, 1504, 1679 i nast., http:// biblia.pentruviata.ro/robible.php [dostęp: 30.06.2020]); z drugiej strony w Biblii Karola II Jozuego nazywa się Iosua, ale pozostałe dwie postaci, Jezus, syn Syracha, i Jezus Chrystus noszą to samo imię Iisus (Biblia adică Dumnezeiasca Scriptură a Vechiului și a Noului Testament, thum. V. Radu, G. Galaction, București 1939, s. 224, 976, 1099 i nast.).

31 C. Ghioancă, Isus sau Iisus? Care este varianta corectă?, http://bisericaadonai.ro/isus-sau-iisus/ [dostęp: 14.08.2020].

32 E. Munteanu, op. cit., s. 33.

33 C. Pastor, Cum scriem corect: Iisus Hristos, Isus Cristos sau Isus Christos, http://safiisanatos.ro/ sanatate-spirituala/credinta-si-religie/cum-scriem-correct-iisus-hristos-isus-cristos-sau-isus-christos/ [dostęp: 14.08.2020].

34 Za punkt wyjścia do ustalenia form imienia 'Jezus Chrystus' używanych przez poszczególne wyznania posłużyły ich statuty zamieszczone na stronie Sekretariatu Stanu ds. Wyznań Religijnych (Secretariatul de Stat pentru Culte): http://culte.gov.ro/?page_id=57 [dostęp: 10.06.2020]; jeśli w statucie 


\begin{tabular}{|c|c|}
\hline Biserica Ortodoxă Română & Iisus Hristos \\
\hline Episcopia Ortodoxă Sârbă de Timișoara & $?$ \\
\hline Biserica Ortodoxă Rusă de Rit Vechi din România & Isus Hristos \\
\hline Biserica Greco-Catolică & Isus Cristos \\
\hline Biserica Romano-Catolică & Isus Cristos \\
\hline Arhiepiscopia Bisericii Armene & Iisus Hristos \\
\hline Biserica Evanghelică C.A. din România & Iisus Hristos \\
\hline Biserica Evanghelică Lutherană din România & Isus Cristos \\
\hline Biserica Reformată din România & Isus Hristos \\
\hline Biserica Unitariană din Transilvania & Isus Hristos \\
\hline Cultul Creștin Baptist & Isus Hristos \\
\hline Cultul Creștin Penticostal & Isus Hristos \\
\hline Biserica Evanghelică Română & Isus Hristos \\
\hline Biserica Adventistă de Ziua a Șaptea din România Religioasă „Martorii lui Iehova” & Isus Cristos \\
\hline Cres̆ După Evanghelie din România & Isus Cristos \\
\hline
\end{tabular}

Mogłoby się wydawać, że problem natury formalnej - ortograficznej, taki jak sposób zapisu imienia Jezusa Chrystusa, ma drugorzędne znaczenie. Należy jednak pamiętać, że dotyczy on postaci uważanej przez wszystkie te wyznania za ich centralną postać, Boga i/lub Zbawiciela. Ponadto każde z tych wyznań cechuje pewien (choć różnie się przejawiający) formalizm: prawosławie i katolicyzm wykazują silne przywiązanie do tradycji, a protestantyzm - do litery Pisma. W przypadku starowierców rosyjskich kwestia poprawnego zapisu imienia "Jezus" stała się wszak jedną z przyczyn samego rozłamu i krwawych prześladowań wyznawców „starej wiary” w ich rosyjskiej ojczyźnie. Reformy patriarchy Nikona (lata 50. XVII w.) przywracały bowiem starszą pisownię imienia Jezus przez podwójne $<$ ii $>$ w miejsce stosowanego na Rusi uproszczonego zapisu przez jedno $<\mathrm{i}>$, podczas gdy dla starowierców była to tradycyjna i jedyna słuszna pisownia ${ }^{35}$. $\mathrm{Z}$ tego powodu również w języku ru-

nie ma odniesienia do Jezusa Chrystusa (sic!), informacje podane w tabeli opierają się na analizie dostępnych w Internecie tekstów firmowanych przez oficjalną reprezentację danego wyznania.

35 J.H. Billington, Ikona i topór. Historia kultury rosyjskiej, Kraków 2008, s. 123-125. 
muńskim starowiercy rosyjscy używają pisowni Isus Hristos, z jednym $<\mathrm{i}>$, tak jak w swoim języku liturgicznym, cerkiewnosłowiańskim (abstrahując oczywiście od kwestii różnych alfabetów). Różnice pod tym względem występują również pomiędzy luteranami obu działających w Rumunii denominacji: ewangelicko-augsburskiej dla luteranów niemieckich (tzw. Sasów siedmiogrodzkich) i ewangelicko-luterańskiej dla luteranów węgierskich i słowackich. W liturgii Kościoły te raczej nie posługują się rumuńskim, lecz językami swoich wiernych, jednak w swoich oficjalnych statutach w języku rumuńskim luteranie niemieccy używają „prawosławnej” wersji Iisus Hristos, a luteranie węgierscy i słowaccy - „katolickiej” Isus Cristos, mimo że w ojczystych językach wszystkich tych mniejszości występują formy wymawiane przez /k/: niem. Jesus Christus, węg. Jézus Krisztus, słow. Ježiš Kristus. Ormianie rumuńscy z kolei, mimo że w swoim języku liturgicznym, grabarze (staroormiańskim), używają formy Hisus Cristos (przez /k/), w języku rumuńskim posługują się formą Iisus Hristos ${ }^{36}$ (wymawianą przez /x/). W przypadku wyznań mających charakter Kościołów narodowych różnych mniejszości wybór formy rumuńskiej może zatem zależeć (choć nie musi) od wpływu ich własnych języków. Należy zauważyć, że wariant kompromisowy, tj. pisownia $I(i)$ sus Christos, nie występuje raczej w codziennej praktyce rumuńskich Kościołów chrześcijańskich. Jej użycie ograniczone jest w zasadzie do tekstów neutralnych wyznaniowo (jak np. prace religioznawcze czy historyczne).

$\mathrm{Na}$ marginesie dodajmy również, że podobne różnice w formie imienia 'Jezus Chrystus', tyle że bardziej konsekwentnie uwarunkowane wyznaniowo, występują w serbskim i chorwackim oraz $\mathrm{w}$ dwóch podstawowych odmianach albańskiego, toskijskiej i gegijskiej. Warianty: serbski i toskijski mają oczywiście wydźwięk ,prawosławny”, zaś formy używane w chorwackim i gegijskim - „katolicki”:

\begin{tabular}{|c|c|}
\hline serbski & Isus Hrist \\
\hline chorwacki & Isus Krist \\
\hline \multicolumn{2}{|c|}{} \\
\hline toskijski & Jisu Krishti \\
\hline gegijski & Jezu Krishti \\
\hline
\end{tabular}

Pomijając spontaniczne przypadki wymiennego użycia różnych synonimicznych terminów, różnice w rumuńskiej terminologii religijnej są najczęściej wynikiem świadomej polityki językowej nowszych wyznań (katolickich i protestanckich) - nawet w przypadku tych samych pojęć wprowadza się nowe terminy, łacińskie lub romańskie, aby w ten sposób odróżnić się również zewnętrznie i formalnie od tradycyjnego

36 Tak np. w thumaczeniu liturgii ormiańskiej na rumuński w publikacji: A. Mandalian, M. \& H. Tavitian, L. Terzian, Taina Sfintei Liturghii a Bisericii Apostolice Armene pe înțelesul tuturor, București 2003. 
i większościowego w Rumunii prawosławia, stosującego w dużej mierze terminologię grecko-słowiańską. W ten sposób podziały wyznaniowe w łonie chrześcijaństwa przekładają się na opozycje natury leksykalnej (autochtonizmy vs neologizmy), nie zawsze jednak oczywiste i konsekwentne.

\section{BIBLIOGRAFIA}

\section{Źródla:}

Legea $n r$. 489/2006 privind libertatea religioasă, http://www.arhiva.culte.gov.ro/_site/culte/detaliu-legis latie/vrs/IDleg/18.html [dostęp: 15.06.2020].

Biblia adică Dumnezeiasca Scriptură a Legii Vechi și a Celei Nouă, București 1914.

Biblia adică Dumnezeiasca Scriptură a Vechiului și a Noului Testament, thum. V. Radu, G. Galaction, București 1939.

Biblia sau Sfânta Scriptură, București 1997.

Biblia sau Sfânta Scriptură, thum. B.V. Anania, 2012, http://biblia.pentruviata.ro/robible.php [dostęp: 12.06.2020].

Boska Liturgia świętego ojca naszego Jana Chryzostoma, tłum. H. Paprocki, http://www.liturgia.cerkiew. pl/pages/File/docs/urgia_jana_chryzostoma.pdf [dostęp: 15.05.2020]).

Boska Liturgia świętego ojca naszego Jana Chryzostoma, w: Liturgie Kościoła prawosławnego, thum. H. Paprocki, Kraków 2003, s. 61-125.

Crezul - Tatăl nostru în unsprezece limbi, București 2015.

Gheție I., Fragmentul Todorescu. Text stabilit, studiu filologic, studiu lingvistic și indice de Ion Gheție, w: Texte românești din secolul al XVI-lea, red. I. Gheție, București 1982, s. 259-364.

Liturghia Sfântului Ioan Gură-de-Aur, w: Carte de rugăciuni, http://www.greco-catolic.ro/rugaciuni. asp?autor=gotia\&id=10 [dostęp: 10.07.2020].

Mandalian A., Tavitian M. \& H., Terzian L., Taina Sfintei Liturghii a Bisericii Apostolice Armene pe ințelesul tuturor, București 2003.

Podlaski G. (red.), Молитвословъ. Modlitewnik prawosławny, Białystok 2002.

Preces. Carte de rugăciuni, Iași 1996, http://www.ercis.ro/liturgie/preces.asp?id=14 [dostęp: 10.07. 2020].

Sfânta și Dumnezeiasca Liturghie a Sfântului Ioan Gură de Aur, w: Carte de rugăciuni, Alba Iulia 2003, s. $194-250$.

\section{Korpusy i słowniki językowe:}

CoRoLa. Corpus computațional de referință pentru limba română contemporană, http://corola.racai.ro/ [dostęp: 10.08.2020].

DER = Ciorănescu A., Dicționarul etimologic al limbii române, tłum. T. Șandru Mehedinți, M. Popescu Marin, București 2002.

DEX = Coteanu I., Mareș L. (red.), Dicționarul explicativ al limbii române, București 1998, https:// dexonline.ro/ [dostęp: 12.07.2020].

DLRLC = Rosetti A. (red.), Dicționarul limbii romîne literare contemporane, București 1955-1957, https://dexonline.ro/ [dostęp: 12.07.2020].

DOOM = Vintilă-Rădulescu I. (red.), Dicționarul morfologic, ortografic, ortoepic și morfologic al limbii române (DOOM), București 2005.

MDA = Sala M., Dănăilă I. (red.), Micul dicționar academic, București 2010, https://dexonline.ro/ [dostęp: 12.07.2020].

MDN = Marcu F., Marele dicționar de neologisme, București 2000, https://dexonline.ro/definitie/ CR\%C3\%8DST [dostęp: 10.09.2020]. 


\section{Opracowania i artykuly:}

Billington J.H., Ikona i topór. Historia kultury rosyjskiej, Kraków 2008, s. 123-125.

Ghioancă C., Isus sau Iisus? Care este varianta corectă?, http://bisericaadonai.ro/isus-sau-iisus/ [dostęp: 14.08.2020].

Klimkowski T., Autochtonizmy i neologizmy w rumuńskiej terminologii prawniczej w kontekście przektadu polsko-rumuńskiego, w: Norma a uzus II. Przeklad specjalistyczny w perspektywie globalizacji, red. B. Walkiewicz, K. Kęsicka, Poznań 2017, s. 79-92.

Klimkowski T., Influențe slave vechi asupra morfologiei și sintaxei limbii române, Alba Iulia 2011.

Munteanu E., Un caz de inconsecvență ortografică cu motivație confesională: I(i)sus H(ch)ristos, „Anuar de Lingvistică și Istorie Literară”, 2004-2006, t. 44-46, s. 31-43.

Pastor C., Cum scriem corect: Iisus Hristos, Isus Cristos sau Isus Christos, http://safiisanatos.ro/sanatatespirituala/credinta-si-religie/cum-scriem-correct-iisus-hristos-isus-cristos-sau-isus-christos/ [dostęp: 14.08.2020].

Stoian I.M., Dicționar religios, București 1994, https://dexonline.ro/definitie/Hrist [dostęp: 15.07.2020]. 